QUEIROGA, RCF; SILVA, GD; PEREIRA, AM; ALMEIDA, RRP; SILVA, AB. 2017. Yield and quality of the Tetsukabuto squash fruits induced with 2,4-D doses under dry conditions. Horticultura Brasileira 35: 271-277 DOI - http://dx.doi.org/10.1590/S0102-053620170219

\title{
Yield and quality of the Tetsukabuto squash fruits induced with 2,4-D doses under dry conditions
}

\author{
Roberto CF Queiroga; Gabriel D Silva; Auderlan M Pereira; Ricardo RP Almeida; Ariano B Silva \\ Universidade Federal de Campina Grande (UFCG), Pombal-PB, Brasil; robertoqueiroga@ccta.ufcg.edu.br (autor para correspondência); \\ gabriel.dourado10@gmail.com; auderlanpereira@bol.com.br; ricelli2008@bol.com.br; ariano@gmail.com
}

\begin{abstract}
Squashes and pumpkins are known and grown worldwide, including the Tetsukabuto type, a hybrid of Japanese origin. On this work, we evaluated yield and quality of parthenocarpic fruits of hybrid Tetsukabuto developed with the use of 2,4-D doses, in the climatic conditions of the Brazilian semiarid, in the city of Pombal, state of Paraíba, Brazil. The experiment was carried out from February to May 2013, in complete blocks at random and five replications. Treatments corresponded to five 2,4-D doses $(0,90,180,270$, and $360 \mathrm{mg} / \mathrm{L}$ ) applied to female flowers, and a control treatment, where fruits developed out of insect pollinated flowers. We evaluated number of flowers per plant, duration of flowering, number of fruits per plant (used to estimate number of fruits per hectare), fruit set index, fruit mass and transversal and longitudinal diameters, pulp thickness and content of soluble solids, total fruit production and yield. Number of fruits per plant and fruit mass increased 269.5 and $15.4 \%$, respectively, with $212.1 \mathrm{mg} / \mathrm{L}$ and $360.0 \mathrm{mg} / \mathrm{L}$ of 2,4-D, when compared to the control treatment. Increasing the 2,4-D dose from 0.0 to $241.4 \mathrm{mg} / \mathrm{L}$ resulted in $38.2 \%$ rise in plant production. Correlations were significant only for number of flowers $\mathrm{x}$ number of fruits per plant (NF) and NF x yield, with coefficients of 87.5 and $82.7 \%$, respectively. These results indicate that fruit induction using 2,4-D resulted in higher fruit set, independent of the 2,4-D dose applied.
\end{abstract}

Keywords: Cucurbita maxima, Cucurbita moschata, phytohormone, physiology.

\section{RESUMO}

Produção e qualidade de frutos de abóbora Tetsukabuto com doses de 2,4-D sob condição de sequeiro

As abóboras e morangas são amplamente conhecidas e cultivadas em todo o mundo, em especial o tipo Tetsukabuto, um híbrido de origem japonesa. $\mathrm{O}$ objetivo deste trabalho foi avaliar a produção e qualidade de frutos da abóbora híbrida Tetsukabuto submetida a doses de 2,4-D nas condições climáticas do semiárido brasileiro, no município de Pombal-PB. O experimento foi conduzido de fevereiro a maio de 2013, em blocos casualizados, com cinco repetições. Os tratamentos corresponderam a cinco doses de 2,4-D (0, 90, 180, 270 e $360 \mathrm{mg} / \mathrm{L}$ ), aplicadas nas flores femininas, e um tratamento testemunha em que os frutos se desenvolveram a partir de polinização natural. Foram avaliados o número de flores por planta, duração do florescimento, frutos por planta (utilizado para estimar o número de frutos por hectare), índice de frutificação, massa e diâmetros médios transversal e longitudinal dos frutos, espessura e teor de sólidos solúveis da polpa, produção e produtividade total. O número de frutos por planta e a massa do fruto aumentaram $269,5 \%$ e $15,4 \%$ com as doses de 212,1 mg/Le 360,0 mg/L de 2,4-D, respectivamente, quando comparados à testemunha. $\mathrm{O}$ incremento na dose de 2,4-D de 0,0 a $241,4 \mathrm{mg} / \mathrm{L}$ elevou em $38,2 \%$ a produção da planta. A correlação foi significativa apenas para número de flores $\mathrm{x}$ número de frutos por planta (NF) e para NF x produtividade, com coeficientes de 87,5 e $82,7 \%$, respectivamente. Estes resultados indicam que a indução da frutificação com 2,4-D proporcionou maior pegamento de frutos independente da dose aplicada.

Palavras-chave: Cucurbita maxima, Cucurbita moschata, fitohormônio, fisiologia.

\section{Received on November 18, 2015; accepted on September 9, 2016}

$\mathrm{S}$ quashes and pumpkins have high socioeconomic importance in many parts of Brazil. In 2010, the country produced around $384,913 \mathrm{t}$ of squashes and pumpkin, in a total harvested area of 88,20 ha. In the Northeast region and particularly in the state of Paraíba, total production reached 92,90 and 3,48 $\mathrm{t}$, in 45,91 and 5,00 ha, respectively (IBGE, 2015). Among squashes, the "Tetsukabuto" hybrid is preferred when compared to regular types, due to its fruits with orange, thick and rather firm pulps, with total solid contents ranging from 12 to $18 \%$, and resistant to postharvest handling and transportation. In addition, Tetsukabuto plants have wide adaptation, and are early and uniform. Mature fruits are excellent sources of retinol, pro-vitamin A, carbohydrates, vitamin $\mathrm{B}$, calcium, iron and phosphorus (Miranda, 2012).
The Tetsukabuto hybrid is obtained by crossing pumpkins (Cucurbita maxima) and squashes (Cucurbita moschata). Although it produces male and female flowers in the same plant, the hybrid is considered to be male-sterile, since male flowers are absent or scarce when female flowers are opened. Thus, to avoid low fruit set, seeds of other Cucurbita species are sown along with hybrid seeds to function as pollen source 
for the entomophilic cross-pollination (Pedrosa et al., 2012).

An alternative to mitigate pollination failures and thus to ensure perfect fruit development in Tetsukabuto-like squashes is the use of chemical substances that stimulate parthenocarpy (Magalhães, 2013). The development of parthenocarpic fruits, that is, without ovule fertilization, is induced through exogenous application of growth regulators, such as 2,4-dichlorophenoxyacetic acid, in short 2,4-D, at appropriate doses. Low concentrations induce plant growth, with effects similar to auxin or indoleacetic acid (AIA). On the other hand, high concentrations have inverse effects, leading to the complete lack of regulation of plant's main metabolic processes (Pereira, 1999).

Auxins are associated with fruit set. Flower ovaries produce significant amounts, and so do pollen grains (Mota Filho et al., 2012). In tomato, the application of growth regulators, specifically auxins, has led to both ovary and parthenocarpic fruit development (Jong et al., 2016). In Tetsukabuto-like squashes, the use of growth regulators has induced increases of up to $200 \%$ in yield in disease-free and well-managed fields, compared to other cultural practices. Thus, the use of plants as pollen sources may be no longer necessary as a cultural practice in Tetsukabuto production, saving up to $20 \%$ of the planted area which are usually dedicated to pollen sources, and avoiding low fruit set due to problems related to climatic conditions, which may compromise bee pollination (Pasqualetto et al., 2001). Phytoregulators of the auxin group may replace the use of pollen sources as a means to ensure and increase fruit set in hybrid squash production.

Miranda (2012), evaluating agronomic characteristics of Tetsukabuto fruits as function of 2,4-D doses (187.5, $200.0,212.5,225.0,237.5,250.0$ and $262.5 \mathrm{mg} / \mathrm{L}$ of 2, 4-D) used as phytohormonal inducer, and comparing them to those of control plants (flowers fertilized with pollen), observed that average fruit weight, yield and plant cycle were advantageous with the use of 2,4-D when compared to natural pollination; and increments in 2,4-D doses led to increases in yield and fruit mean weight up to $250 \mathrm{mg} / \mathrm{L}$ of 2,4-D. In another study to improve Tetsukabuto fruit set and ensure adequate fruit development, Pasqualetto et al. (2001) evaluated crop performance as function of increasing 2,4-D doses $(0,50,100$, 150 and $200 \mathrm{mg} / \mathrm{L}$ ) applied to female flowers, and observed that $150 \mathrm{mg} / \mathrm{L}$ of 2,4-D tended to increase fruit number and average weight per plant, resulting in $68.1 \%$ increase in production in relation to the control.

Despite the work already done, there is still very little information available on the effects of doses and application of 2,4-D on female flowers over hybrid squash production. And information becomes even more occasional for border growing conditions, such as the semiarid, which is characterized by high temperatures and low precipitation. In Brazil, the semiarid occurs in the Northeast region, including the state of Paraíba, where this work was carried out.

Our objective was to evaluate fruit production and quality on Tetsukabuto hybrid squash submitted to different 2,4$\mathrm{D}$ doses under the growing conditions of the city of Pombal, state of Paraíba, Brazil.

\section{MATERIAL AND METHODS}

The experiment was carried out in the campus of the Center for Agrifood Science and Technology of the Federal University of Campina Grande, in the city of Pombal $\left(06^{\circ} 46^{\prime} \mathrm{S}\right.$; $37^{\circ} 48^{\prime} \mathrm{W}$, altitude 184 meters) (Beltrão, 2005), state of Paraíba, Brazil, from February to May, 2013. The soil at the experimental station is a Fluvic Entisol (Embrapa, 2006), with the following attributes in the arable layer: sand $=472 \mathrm{~g} / \mathrm{kg}$; silt $=$ $332 \mathrm{~g} / \mathrm{kg}$; clay $=196 \mathrm{~g} / \mathrm{kg}$; $\mathrm{pH}$ in $\mathrm{H}_{2} \mathrm{O}=$ 5.9; $\mathrm{Ca}^{2+}=7.8 \mathrm{cmolc} / \mathrm{dm}^{3} ; \mathrm{Mg}^{2+}=6.3$ cmolc $/ \mathrm{dm}^{3} ; \mathrm{K}^{+}=0.32 \mathrm{cmolc} / \mathrm{dm}^{3} ; \mathrm{Al}^{3+}=$ $0.20 \mathrm{cmolc} / \mathrm{dm}^{3} ; \mathrm{CEC}=16.11 \mathrm{cmolc} /$ $\mathrm{dm}^{3} ;$ base saturation $=94.0 \% ; \mathrm{P}=45$ $\mathrm{mg} / \mathrm{dm}^{3}$ and organic matter $=26.0 \mathrm{~g} / \mathrm{kg}$. The climate is tropical wet and dry (Aw), according to the Köppen classification.

Treatments corresponded to doses of 2,4-D: 0, 90, 180, 270 and $360 \mathrm{mg} / \mathrm{L}$. To meet these concentrations, we made the necessary dilutions on a solution prepared with the dimethyl amine salt of the 2,4-dichlorophenoxyacetic acid, $806 \mathrm{~g}$ active ingredient per liter. At the null dose $(0.0 \mathrm{mg} / \mathrm{L}$ of $2,4-\mathrm{D})$, fruit set was ensured by keeping hybrid flowers freely accessible to pollinators, in the presence of a pollen source. The experimental design was complete blocks at random, with five replications. Experimental plots consisted of single 20-m lines, with five plants, in $80 \mathrm{~m}^{2}$ in total.

We sowed the Tetsukabuto hybrid and the pumpkin cultivar Exposição (pollen source) in 128-cell polystyrene trays, containing commercial agricultural substrate suitable for vegetable seedlings. The hybrid was sown on February 10, 2013, and the pollen source, twelve days before, to ensure flowering synchronization. Trays were placed in greenhouse and irrigated three times a day, for fifteen days, when seedlings presented two pairs of leaves and were transplanted (February 25, 2013), one seedling per pit in the field.

Soil preparation consisted of harrowing and hilling, with $4.0 \mathrm{~m}$ between furrows and $20 \times 20 \times 20 \mathrm{~cm}$ pits. We installed a localized drip irrigation system, using self-compensating irrigators of 2,7 L/hour flow, used for irrigation and fertigation. We preferred to use wide spacing due to the vigorous vegetative growth of squash plants in the region, especially in the rainy season. Dense spacing makes it difficult to manage plants and experimental procedures properly, especially treatment application and evaluations, due to vine interweaving.

Side fertilization consisted only of daily fertigation, started three days after transplanting. Sources of nitrogen and potassium were urea and potassium chloride, respectively, at 60 and 80 $\mathrm{kg} / \mathrm{ha}$. Each fertigation delivered the following percentages of each nutrient: first $=5.0 \% \mathrm{~N}$ and $7.0 \% \mathrm{~K}_{2} \mathrm{O}$; second $=$ $8.0 \% \mathrm{~N}$ and $10.0 \% \mathrm{~K}_{2} \mathrm{O}$; third $=10.0 \%$ $\mathrm{N}$ and $8.0 \% \mathrm{~K}_{2} \mathrm{O}$; from the fourth to the sixth $=20.0 \% \mathrm{~N}$ and $18.0 \% \mathrm{~K}_{2} \mathrm{O}$; seventh $=7.0 \% \mathrm{~N}$ and $7.0 \% \mathrm{~K}_{2} \mathrm{O}$; eighth and ninth $=5.0 \% \mathrm{~N}$ and $7.0 \% \mathrm{~K}_{2} \mathrm{O}$. 
Treatments started from flowering. Female flowers were protected with paper bags a day before anthesis to prevent interference from pollinator insects. In the following morning, bags were removed and treatments applied: two $1.0 \mathrm{~mL}$-jet inside the flower, in all useful plants on the plot, using an accumulated pressure hand sprayer. After spraying, flowers were protected again to avoid interference with treatments and, later, with results. We removed the paper bags when we noticed fruit set or flower abortion.

Pest control was carried out with the active principles chlorpyrifos and thiamethoxam, using insecticides registered for the crop. A preventive application was scheduled soon after transplanting and another two, with 15day intervals. All sprayings were run late in the afternoon. Caterpillars, aphids and whiteflies were the most frequent pests during the experiment.

Harvest began on May 11, 2013, 86 days after sowing, and ended when the crop cycle completed 99 days. We evaluated the following characteristics in all plants on experimental plots: number of female flowers per plant (daily count), duration of flowering (number of days between the onset of the first and last flower); fruit set index (ratio between the number of flowers that set fruit and the number of flowers in which 2,4-D was applied to), and; number of fruits per plant (counting), which was later used to estimate the number of fruits per hectare.

For the other characteristics, we used a five-fruit sample per plot, totaling 25 fruits per treatment: fruit mass $(\mathrm{g})$, obtained through weighing; fruit diameters $(\mathrm{cm})$, measured in the transverse and longitudinal directions with a ruler; pulp thickness $(\mathrm{cm})$, measured with a ruler in the middle part of the fruit; soluble solids content ( ${ }^{\circ}$ Brix), evaluated in ATAGO PAL1 refractometer, using the juice of a longitudinal pulp slice crushed in centrifuge, and; total fruit weight per plant ( $\mathrm{kg} / \mathrm{plant})$, used to estimate total yield (kg/ha).

We studied the association (Pearson's correlation) between the following characteristics: number of female flowers per plant (NFFP) x number of fruits per plant (NFP); NFP $\mathrm{x}$ fruit mass (FM); NFP x yield (YLD) and FM x YLD. Analysis of variance for all characteristics was run using software SAEG 9.0, with 5\% as significance level. As the nature of treatments we applied is quantitative (doses of 2,4-D), we also performed regression analysis, using software Table Curve 2D.

\section{RESULTS AND DISCUSSION}

Doses of 2,4 D significantly influenced number of fruits per plant and, consequently, per hectare, and fruit set index in Tetsukabuto hybrid squashes $(P<0.05)$. No significant differences due to the use of 2,4-D stood up on number of female flowers per plant, duration of flowering and fruit mass.

Nevertheless, when the regression analysis was applied, we observed that number of female flowers per plant had quadratic response to 2,4-D doses, with an estimated maximum of 20.3 flowers at $219.0 \mathrm{mg} / \mathrm{L}$ of 2,4-D. Considering that the lowest number of female flowers per plant, 14.9 (Figure 1), was observed at the control treatment, the use of 2,4$\mathrm{D}$ resulted in $36.2 \%$ increase in the characteristic. Duration of flowering also presented a quadratic response: the longest flowering period, 18.8 days, was observed at $230.7 \mathrm{mg} / \mathrm{L}$ of 2,4-D, and the shortest, only 9.1 days, in the control treatment (Figure 1). Thus, 2,4D doubled the plant flowering duration (106.6\% increase), extending it in 9.7 days.

We observed the peak of female flowers per plant at $219.0 \mathrm{mg} / \mathrm{L}$ of 2,4-D. However, at $230.7 \mathrm{mg} / \mathrm{L}$ of 2,4-D, the blooming period was the longest. The strength of the drain (flowers and fruits) may have limited flower emission from $219.0 \mathrm{mg} / \mathrm{L}$ of 2,4-D, that is, plants had less female flowers and thus bloomed for a longer period. In cucurbits, after anthesis, plants with large numbers of fruits are affected by the drain strength, which inhibits the development of more flowers, especially female flowers (Valantim Morinson et al., 2006).

Number of fruits per plant, and thus per hectare, presented quadratic response to the application of 2,4-D, with maximum values of 8.5 fruits/ plant, 7,050.4 fruits/ha, at $212.1 \mathrm{mg} / \mathrm{L}$ of 2,4-D. As control plants produced the lowest number of fruits, 2.3 fruits/plant, 1,899.5 fruits/ha (Figure 1), we may postulate that the use of 2,4-D resulted in $269.5 \%$ increase in number of fruits. This figure is close to that observed for number of flowers per plant with the optimal dose of $219.0 \mathrm{mg} / \mathrm{L}$ of 2,4-D, which reveals that both characteristics reacted similarly to the application of 2,4-D. In fact, number of flowers and fruits per plant had a significant direct linear correlation with each other, with a correlation coefficient as high as 0.8753 .

Our estimates for number of fruits per plant, with a maximum of 8.5 fruit/plant with $212.1 \mathrm{mg} / \mathrm{L}$ of $2,4-\mathrm{D}$, are higher than those observed by Pasqualetto et al. (2001) working also with Tetsukabuto hybrids and 2,4-D doses $(0,50,100,150$ and $200 \mathrm{mg} / \mathrm{L})$, who reported a peak of 6.6 fruits/plant at $150.0 \mathrm{mg} / \mathrm{L} 2,4-\mathrm{D}$. Our figures are also above those of Magalhães (2013), whose highest value for number of fruits/plant was 2.2 , obtained in the dose $700 \mathrm{mg} /$ $\mathrm{dm}^{3}$ of 2,4-D, using cultivar Zapallo.

Fruit set index also showed quadratic response to the application of 2,4-D, with maximum, $87.3 \%$, and minimum, $45,8 \%$, estimated values, observed for 218.4 and 0.0 2,4-D mg/L, the control treatment, respectively (Figure 1). Considering this result, we may say that there was $90.5 \%$ increase in fruit set index in Tetsukabuto squash as function of 2,4-D. The optimum dose for fruit set index is very close to that obtained for number of female flowers per plant $(219.0 \mathrm{mg} / \mathrm{L}$ of $2,4-\mathrm{D})$ and number of fruits per plant $(212.1 \mathrm{mg} /$ $\mathrm{L}^{1}$ of 2,4-D). This strengths the close relation between fruit set and number of female flowers, meaning that number of fruits will increase with number of female flowers per plant up to the limit when internal competition among drains leads to flower abortion, as observed for 2,4-D doses above $218.4 \mathrm{mg} / \mathrm{L}$.

Fruit mass increased linearly with 2,4-D doses, with estimates of minimum and maximum of 1,964 and $2,267 \mathrm{~kg} /$ fruit at 0,0 (control) and $360,0 \mathrm{mg} / \mathrm{L}$ of 2,4-D, respectively. Such variation 


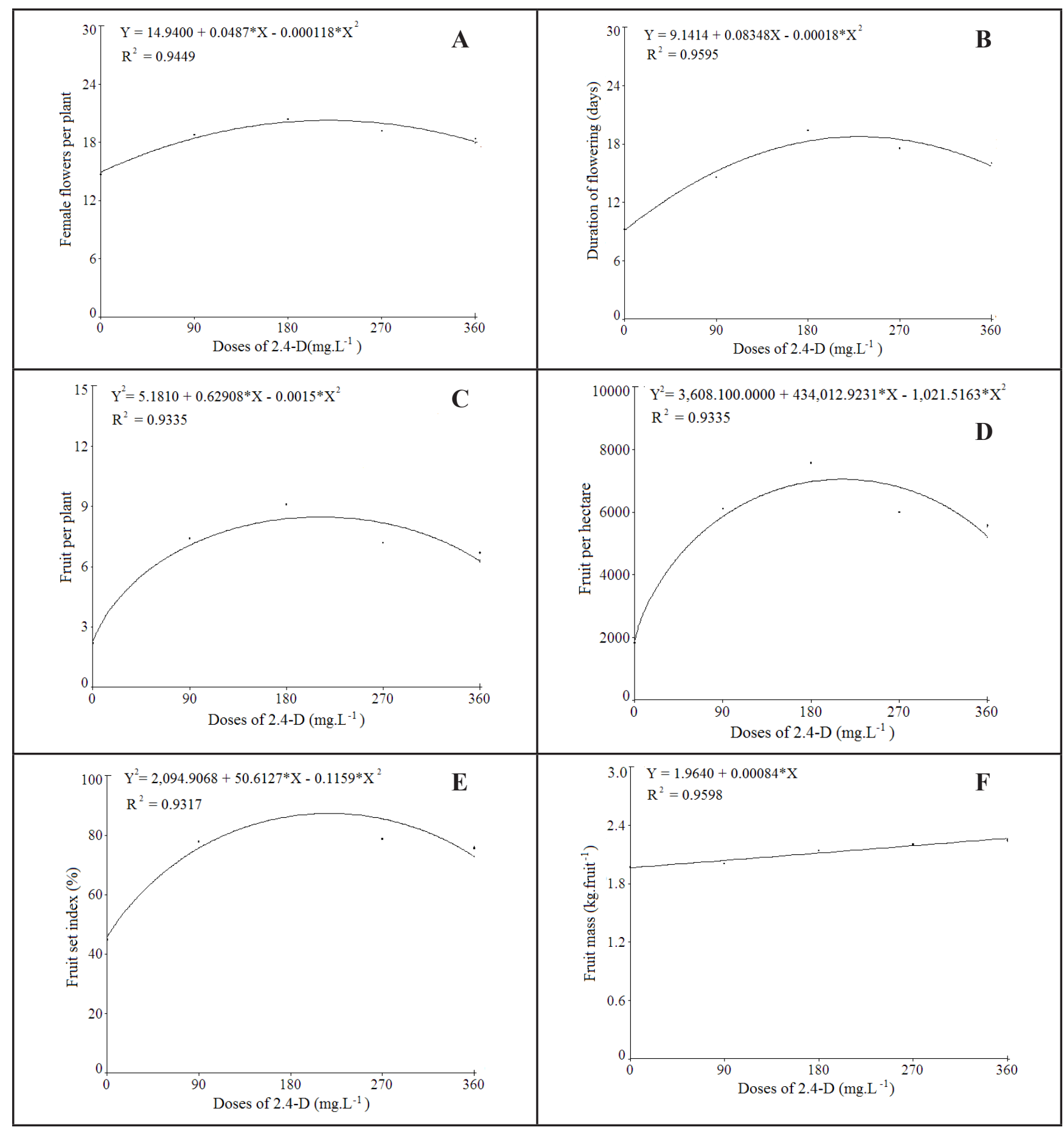

Figure 1. Adjusted response functions of female flowers per plant, duration of flowering, fruits per plant and per hectare, fruit set index and fruit mass in Tetsukabuto hybrid squash subjected to application of 2,4-D on female flowers. Pombal, UFCG, 2013.

corresponds to an increase of $315.0 \mathrm{~g} /$ fruit, that is, $15.4 \%$ (Figure 1). As we previously mentioned, number of fruits per plant declined as the concentration of 2,4-D increased from $212.1 \mathrm{mg} / \mathrm{L}$, while fruit mass continued growing up to the highest concentration we applied (360.0 $\mathrm{mg} / \mathrm{L}$ of $2,4-\mathrm{D})$. We believe that the reduction in number of fruits at 2,4-D doses higher than $212.1 \mathrm{mg} / \mathrm{L}$ allowed for higher assimilate intake by the remaining fruits, therefore resulting in fruit mass increases due to the source and drain balance. Lower fruit set in cucurbit plants contribute to increasing fruit mass due to the reduced competition for assimilate partition (Valantim Morinson et al., 2006). However, it is important to point out that in markets that sell whole fruits, consumers prefer fruits weighting less than $3.0 \mathrm{~kg}$ (Magalhães, 2013).

Values for fruit mass we are reporting here are higher than those observed by 


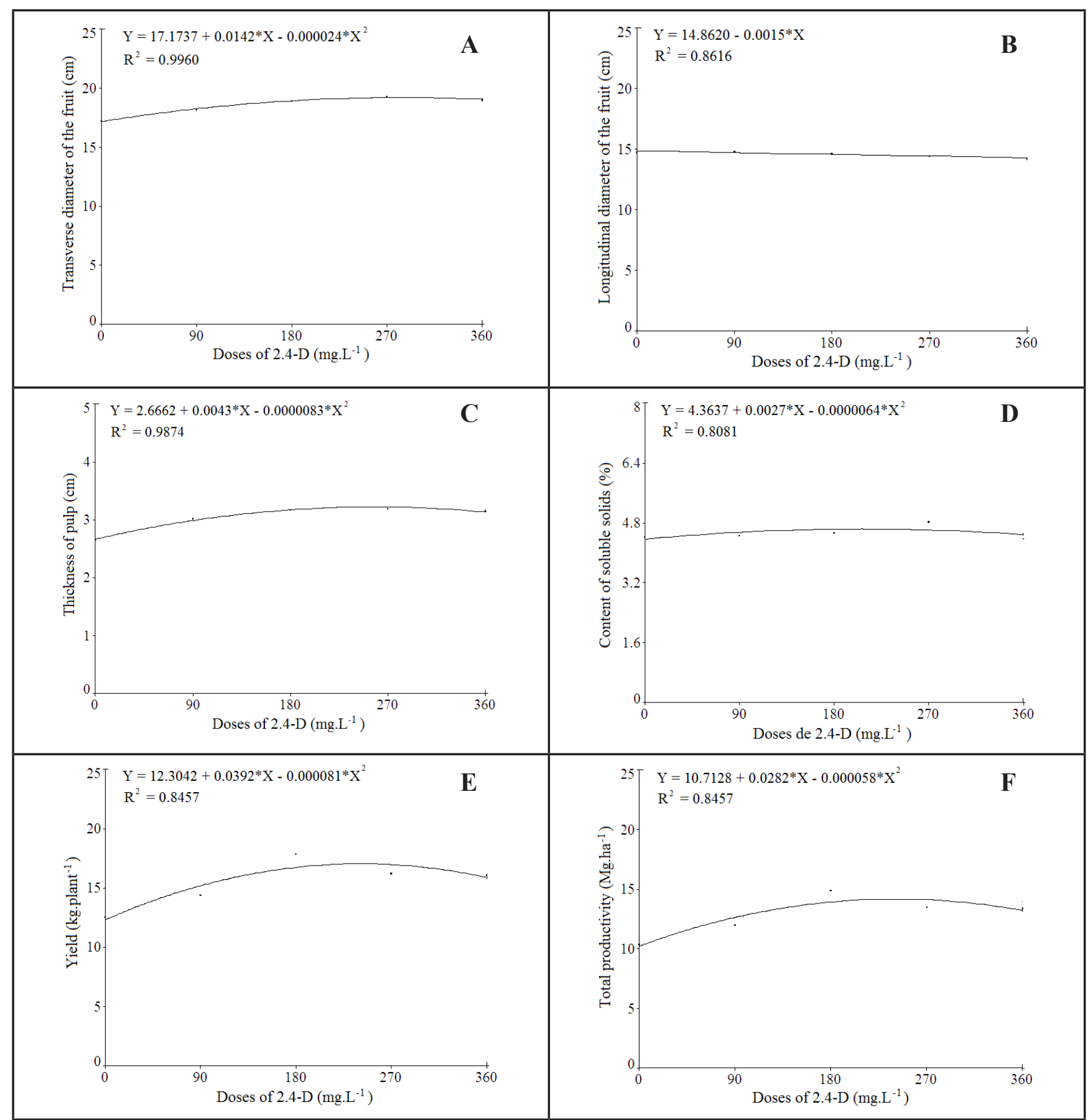

Figure 2. Adjusted response functions of fruit transverse and longitudinal diameter, pulp thickness and content of soluble solids, and total fruit yield and productivity in Tetsukabuto hybrid squash subjected to application of 2,4-D on female flowers. Pombal, UFCG, 2013.

Pasqualetto et al. (2001), $1.232 \mathrm{~kg}$ with $150.0 \mathrm{mg} / \mathrm{L}$ of $2,4-\mathrm{D}$, but below those found by Magalhães (2013), $2.68 \mathrm{~kg}$ at $700 \mathrm{mg} / \mathrm{dm}^{3}$ of 2,4-D. More important, fruit mass we found is in line with the Brazilian market requirements, which makes the use of 2,4-D a feasible alternative to change fruit set index and to obtain fruits in sizes that matches consumer's preference.
The application of 2,4-D doses to Tetsukabuto female flowers had no significant effects on fruit longitudinal diameter, pulp thickness, soluble solids content, and yield, either per plant or per hectare $(P \geq 0.05)$. Only fruit transverse diameter varied significantly as function of 2,4-D ( $\mathrm{P} \geq 0.05)$.

Fruit transverse diameter showed quadratic response to 2,4-D doses, with the maximum estimated value of $19.2 \mathrm{~cm}$, in $285.3 \mathrm{mg} / \mathrm{L}$ of $2,4-\mathrm{D}$, and the minimum, $17.2 \mathrm{~cm}$, in the control treatment (Figure 2). The difference corresponds to $11.6 \%$ increase in fruit transverse diameter. Fruit diameter in our work is above reports from Nascimento et al. (2008) with the Tetsukabuto hybrid Jabras, who had estimates for fruit diameter of 15.0 
cm; and from Magalhães (2013), who reported fruits of cultivar Zapallo with transverse diameter of $13.9 \mathrm{~cm}$ when $700 \mathrm{mg} / \mathrm{dm}^{3}$ of 2,4-D were used.

Fruit longitudinal diameter presented linear reverse response to the application of 2,4-D, with estimated maximum and minimum values of 14.9 and $14.3 \mathrm{~cm}$ at 0.0 and $360.0 \mathrm{mg} / \mathrm{L}$, respectively (Figure 2). The small reduction, $0.7 \mathrm{~cm}$, corresponded to $4.9 \%$ decrease in fruit longitudinal diameter, suggesting that Tetsukabuto fruits tend to become flattened with increasing 2,4$\mathrm{D}$ doses. Fruit height is related to width and consequently to size and shape (Silva, 2010). Additionally, the rate longitudinal $\mathrm{x}$ transverse diameters, as well as the diameters per se are relevant commercial attributes, since smaller fruits are usually preferred (Amariz et al., 2010).

Pulp thickness showed quadratic response to the use of 2,4-D, with minimum and maximum estimated values of 2.7 and $3.2 \mathrm{~cm}$ at 0.0 and $257.6 \mathrm{mg} / \mathrm{L}$ of $2,4-\mathrm{D}$, respectively (Figure 2), corresponding to $0.5 \mathrm{~cm}$ $(18.5 \%)$ increase. Pulp thickness is directly related to mass accumulation in fruits and inversely associated with fruit internal cavity (Magalhães et al., 2013). The Brazilian market prefers smaller thick pulp fruits (Bezerra Neto et al., 2006), since more pulp results in better use of fruits for both the industry and consumers.

Doses of 2,4-D also induced slight variations in the content of soluble solids in Tetsukabuto fruits: the estimated minimum and maximum values, 4.3 and 4. $6^{\circ}$ Brix, were observed at 0.0 and 206.8 $\mathrm{mg} / \mathrm{L}$ of 2,4-D, respectively (Figure 2). This corresponded to a $0.3^{\circ} \mathrm{Brix}(7.0 \%)$ increase in soluble solids in pulps of Tetsukabuto fruits. The content of soluble solids is relevant because it is used as an indirect indication of sugar content. Although the determination of soluble solids does not represent the actual sugar content since other substances are also dissolved in the cell, such as vitamins, organic acids, phenols, pectins and pigments; sugars are the most representative component of the soluble solids, with up to $90 \%$ of the total (Chitarra \& Alves, 2001). In the current work, we found low values for soluble solids if compared to those found by Miranda (2012), who reported $9.0^{\circ}$ Brix at harvest for $250.0 \mathrm{mg} / \mathrm{L}$ of 2,4-D. We believe that the relatively low values are associated with the constant rains during the harvesting season, when increases in soil moisture and low radiation due to the overcast sky were observed at the experimental site. These climatic conditions might have concurred to dilute the sugar content in fruit pulps.

Fruit yield per plant had quadratic response to 2,4-D doses, with minimum and maximum values of 12.3 and 17.0 $\mathrm{kg} / \mathrm{plant}$, at 0.0 and $241.4 \mathrm{mg} / \mathrm{L}$ of 2,4-D, respectively (Figure 2), thus representing a 4.7 (38.2\%) increase in plant production due to the use of 2,4-D. From the optimum dose, plant production declined, probably due more to reduction in number of fruits per plant, observed from $212.1 \mathrm{mg} / \mathrm{L}$ of 2,4$\mathrm{D}$, than specifically fruit mass, which continued increasing up to $360.0 \mathrm{mg} / \mathrm{L}$ of 2,4-D. This shows that, although remarkable, the rise we observed in number of fruits per plant (269.5\%) was not enough to significantly increase yield. Yet, one should consider that number of fruits contributed much more to the formation of plant's production than fruit mass, which had a rather limited increase due to the use 2,4-D (15.4\%).

As mentioned earlier, number of fruits per plant and fruit mass are the major yield components in most fruit vegetables, and so does in squash. In this work, we observed quadratic response, with minimum and maximum estimated values of 10.72 and $14.11 \mathrm{t} / \mathrm{ha}$, for 0.0 and $241.4 \mathrm{mg} / \mathrm{L}$ of 2,4-D, respectively (Figure 2), that is, $3.4 \mathrm{t} / \mathrm{ha}(31.6 \%)$ increase in crop yield as function of 2,4-D application. Our results were below those of Pasqualetto et al. (2001) who observed that Tetsukabuto plants submitted to $150.0 \mathrm{mg} / \mathrm{L}$ of $2,4-\mathrm{D}$ yielded $68.1 \%$ more than the control. Miranda (2012), on the other hand, found that yield increased with 2,4-D doses, reaching a maximum of $18.73 \mathrm{t} /$ ha with $250.0 \mathrm{mg} / \mathrm{L}$.

Pearson's correlation was significant only for number of flowers $\mathrm{x}$ number of fruits per plant and for number of fruits per plant $x$ productivity, with correlation coefficients of 87.5 and $82.7 \%$, respectively. These correlations indicate that fruit induction by 2,4-D resulted in higher fruit set independent of the applied dose. The increase in number of flowers per plant was proportional to the increase in fruit set. Productivity was significantly dependent on number of fruits per plant $\left(\mathrm{R}^{2}=82.7 \%\right)$, but not on fruit mass $\left(\mathrm{R}^{2}=\right.$ $34.9 \%$, not significant).

The increase in number of fruits (269.5\%) was much more important than the increase in fruit mass (15.4\%) to the formation of productivity. Thus, if the intention is to increase number of fruits, 2,4-D should be applied up to $212.1 \mathrm{mg} / \mathrm{L}$. On the other hand, if the intention is to produce larger fruits, but without reducing yield, then the 2,4D dose should go up to $241.4 \mathrm{mg} / \mathrm{L}$, where the maximum estimated yield was observed (4.1 t/ha), with heavier, but fewer fruits per plant.

\section{ACKNOWLEDGEMENTS}

Authors thank the Center for Agrifood Science and Technology of the Federal University of Campina Grande, for making the experimental area, laboratories and technicians available to this work.

\section{REFERENCES}

AMARIZ, A; LIMA, MAC; ALVES, RE; BORGES, RME; RIBEIRO, TP; COSTA, ACS; PASSOS, MCLMS. 2010. Características físicas de frutos de acesso de abóbora procedentes dos estados do Piauí e do Maranhão. Horticultura Brasileira 28 (Suplemento CD ROM).

BELTRÃO, BA. 2005. Diagnóstico do município de Pombal-PB. Projeto cadastro de fontes de abastecimento por água subterrânea. Ministério de Minas e Energia/CPRM/ PRODEM. Recife, 23 p.

BEZERRA NETO, FV; LEAL, NR; COSTA, FR; GONÇALVES, GM; AMARAL JÚNIOR, AT; VASCONCELOS, HO; MELO, M. 2006. Análise biométrica de linhagem de abóbora. Horticultura Brasileira 24: 378-380.

CHITARRA, AB; ALVES, RE. 2001. Tecnologia de pós-colheita para frutas tropicais. Fortaleza: Instituto Frutal/Sindifruta 1: 314p.

EMBRAPA. 2006. Centro Nacional e Pesquisa em 
Solos. Sistema Brasileiro de Classificação de Solos. Brasilia: Embrapa-SPI; Rio de Janeiro: Embrapa-Solos, 306p.

IBGE, 2015. Censo Agropecuário, 2010. Abóboras (Morangas e Jerimum). Quantidade produzida, área e número de informantes, Brasil e Unidades da Federação. Disponível em: http:// www.sidra.ibge.gov.br. Acessado em 20 de fevereiro de 2015.

JONG, M; MARIANI, C; WRIZEN, WH. 2016. The role of auxin and gibberellin in tomato fruit set. Journal of Experimental Botany 60: 1523-1532.

MAGALHÃES, CG. 2013. Produção e qualidade de abóbora híbrida Tetsukabuto submetida a diferentes aplicações de auxina sintética e adubação nitrogenada. Montes Claros: UNIMONTES. 46p. (Monografia graduação).

MIRANDA, FFR. 2012. Efeito da frutificação induzida por 2,4-D em caracteristicas agronômicas dos frutos de abóbora
'Tetsukabuto'. Tocantins: UFT. 62p. (Dissertação mestrado).

MOTA FILHO, VJG; PEREIRA, MCT; NIETSCHE, S; GUIMARÃES, JFR; MOREIRA, GBR; FERNANDES, TP. 2012. Uso de fitorreguladores no desenvolvimento de frutos na atemoieira (Annona cherimola x A. squamosa cv. Gefner). Revista Ceres 59: 636-645.

NASCIMENTO, WMKG; FREITAS, RA; BOITEUX, LS. 2008. Eficiência de acessos de Cucurbita maxima como polinizadores de abóbora híbrida do tipo "Tetsukabuto". Horticultura Brasileira 26: 540-542.

PASQUALETTO, A; SILVA, NF; ORDONEZ, GP; BARCELOS, RW. 2001. Produção de frutos de abóbora híbrida pela aplicação de 2,4 D nas flores. Pesquisa Agropecuária Tropical 31: 23-27.

PEDROSA, MW; MASCARENHAS, MHT; FREIRE, FM; VIANA, MCM; GONÇALVEZ,
LD; LARA, JFR; FERREIRA, PC. 2012. Produção e qualidade da moranga híbrida em resposta a doses de nitrogênio. Horticultura Brasileira 30: 355-358.

PEREIRA, W. 1999. Recomendações para a frutificação de abóbora híbrida tipo Tetsukabuto: uso de polinizadores e reguladores de crescimento de plantas. Brasília: Embrapa Hortaliças, 7p. (Comunicado Técnico, 12).

SILVA, TB. 2010. Seleção, comportamento genotípico e fenotípico e desenvolvimento de uma nova cultivar de abóbora (Cucurbita moschata Dusch.). São Cristovão: UFS. 46p. (Dissertação mestrado).

VALANTIN-MORINSON, M; VAISSIERE, BE.; GARY, C; ROBIN, P. 2006. Source-sink balance affects reproductive development and fruit quality in cantaloupe melon (Cucumis melo L.). Journal of Horticultural Science \& Biotechnology, 86: 105-117. 